\title{
PENGEMBANGAN MODEL PROJECT-BASED LEARNING UNTUK MENINGKATKAN KEMAMPUAN BAHASA INGGRIS SISWA PONPES MODERN DI MALANG RAYA
}

\author{
Suhartatik, Adi
}

\author{
Email: tatik_sihhanto@yahoo.com \\ Jurusan Pendidikan Bahasa Inggris IKIP Budi Utomo Malang \\ Jalan Simpang Arjuno No. 14-B, Malang
}

\begin{abstract}
English is taught in Modern Islamic Boarding School as one of language competences must be mastered by the students beside Arabic. The teachers find difficulties to implement learning models that make the students to be active and the students need others learning variation. Research and Development (R \& D) design is used in this research that aim to produce the development of "Project Based-Learning Model" plus VCD to improve the Students' English Ability of Modern Islamic Boarding School at Malang Area. The model of development is adopted by Borg and Gall Model starting from collecting information, development of initial product, 1st expert validation, 1st product revision, 2nd expert validation, 2nd product revision, tryout, and final product. The Experts' English Material validation conclude that formulation of learning objective, content, material selection for development of "Project BasedLearning Model" have got category of Excellent. The validation of the Expert of Media conclude that final product of VCD have been appropriated with the aspects of learning media that are feasible to be applied.
\end{abstract}

Keywords: "Project-Based Learning Model", Modern Islamic Boarding School

\section{PENDAHULUAN}

Pengembangan pendidikan pesantren (modern) memiliki tanggung jawab sebagai sekolah umum berciri khas Islam agar mampu meningkatkan kualitas sumber daya manusia. Karena manusia yang berkualitas itu setidaknya memiliki dua kompetensi yaitu kompetensi IMTAQ dan IPTEK. (Ponpes Modern Al-khoirot, 2011, h.1)

Mengacu pada hal tersebut diatas, Bahasa Inggris adalah salah satu mata pelajaran wajib yang diajarkan di Ponpes Modern sebagai salah satu kompetensi bahasa yang harus dimiliki oleh siswa selain Bahasa Arab.

Kompetensi bahasa Inggris yang harus dimiliki oleh siswa pada era globalisasi ini adalah keterampilan komunikasi yang interaktif, dimana siswa dipacu untuk dapat mempraktekkan ketrampilan berkomunikasi sesuai dengan tema yang ada dalam kehidupan sehari-hari, didukung dengan penggunaan model pembelajaran yang dapat memotivasi siswa untuk meningkatkan kemampuan Bahasa Inggris, salah satunya dengan menggunakan "Model Project-Based Learning".

Melihat keunggulan dari "Model Project-Based Learning" yaitu dapat memotivasi siswa untuk mengasilkan suatu proyek atau hasil karya autentik yang dapat meningkatkan kemampuan siswa, maka penggunaan model ini adalah suatu solusi yang tepat dalam mengatasi permasalahan yang dihadapi guru dan siswa.

Hal ini sejalan dengan prinsip-prinsip pengembangan Kurikulum 2013 yang menyatakan bahwa proses belajar dengan 
pendekatan ilmiah (scientific approach) dan penilaian hasil belajar berbasis proses dan produk melalui kegiatan mengamati, menanya, mengeksplorasi, mengasosiasi dan mengkomunikasi (Balitbang Kemdikbud, dalam Mulyasa, 2013, h. 82).

Didukung pula oleh Karakteristik Kurikulum 2013 yang tertuang dalam Kerangka Dasar dan Struktur Kurikulum dirancang untuk mengembangkan keseimbangan antara pengembangan sikap spiritual dan sosial, rasa ingin tahu, kreativitas, kerja sama dengan kemampuan intelektual dan psikomotorik. (Mulyasa, 2013, h. 85)

Menurut hasil analisa kebutuhan, masalah yang ditemui di SMA Ponpes Modern Al-Rifa'ie Gondanglegi, Malang adalah guruguru mengalami kendala dalam menerapkan model-model pembelajaran dan siswa memerlukan teknik atau inovasi pembelajaran lain yang dapat meningkatkan kemampuan Bahasa Inggris. "Model ProjectBased Learning" dikembangkan sesuai dengan karakteristik Kurikulum 2013 adalah solusi dari permasalahan yang ada.

\section{Perumusan Masalah}

Mengacu pada latar belakang dan hasil analisa kebutuhan di lapangan maka rumusan masalah dalam penelitian ini adalah: Bagaimanakah pengembangan "Model Project-Based Learning" untuk meningkatkan kemampuan Bahasa Inggris Siswa Ponpes Modern di Malang Raya?

Adapun tujuan dari penelitian ini adalah untuk menghasilkan suatu produk pengembangan "Model Project-Based Learning" plus VCD pembelajaran untuk meningkatkan kemampuan Bahasa Inggris siswa Ponpes Modern di Malang Raya.

Manfaat dari penelitian pengembangan Model Project Based-Learning ini bagi guru dan bagi siswa Ponpes Modern di Malang Raya adalah sebagai berikut:

1. Bagi Guru Bahasa Inggris, tahap-tahap pengembangan "Model Project-Based Learning" dan hasil produk dari penelitian ini diharapkan dapat memberikan contoh/ model pembelajaran yang inovatif dan dapat merubah kelas yang monoton menjadi kelas yang aktif dan menyenangkan dan dapat dipakai sebagai acuan dalam melaksanakan pendekatan "scientific approach" (kegiatan mengamati, mempertanyakan, mengeksplorasi, mengasosiasi, dan mengkomunikasi) dalam Kurikulum 2013.

2. Bagi Siswa Ponpes Modern pelaksanaan tahap-tahap dan produk dari pengembangan "Model Project Based-Learning" ini diharapkan dapat meningkatkan kemampuan Bahasa Inggris siswa karena siswa dapat mengeksplor kemampuannya untuk menghasilkan sebuah proyek (authentic material) dalam pelajaran Bahasa Inggris, karena siswa dipacu dan dimotivasi untuk dapat menciptakan dan menghasilkan sebuah proyek yang siswa eksplor sendiri, berkolaborasi dengan teman sejawat dalam sebuah kelompok, yang pada akhirnya mereka mengkomunikasikan dalam bentuk display hasil kerja proyek yang dapat meningkatkan kemampuan Bahasa Inggris.

\section{Pengertian "Model Project-Based Learning" (PjBL)}

"Model Project-Based Learning" (PjBL) merupakan model pembelajaran yang melibatkan siswa didalam suatu proyek berdasarkan suatu masalah dan pada akhirnya siswa dapat menghasilkan suatu karya nyata. (Colley, 2008, h.23 dalam Lisminingsih, 2010, h. 112)

Menurut Hodgin (2010, h. 2) "Model Project-Based Learning" (PjBL) lebih menekankan model pembelajaran yang berfokus pada siswa (student-centered) dimana siswa sebagai subjek aktivitas belajar lebih mandiri dalam menyelesaikan karya autentik sebagai hasil pembelajaran.

Kriteria Pembelajaran Berbasis Proyek yaitu keterpusatan, berfokus pada pertanyaan atau masalah, penyelidikan konstruktif atau perancangan, memberi otonomi kepada siswa dan nyata. Komponen utama dari Pembelajaran Berbasis Proyek adalah (1) mengajukan pertanyaan atau masalah yang disajikan untuk menyusun dan memulai aktivitas, dan menekankan kepada sejumlah proyek yang berarti, (2) didapatkannya hasil akhir atau sejumlah produk sebagi rangkaian aktivitas, 
komunikasi individu atau berbagai hasil tugas yang menjawab permasalahan. (Lisminingsih, 2010, h.113)

Ada berbagai kelebihan dalam menerapkan "Model Project-Based Learning" yaitu: 1) Problem Solving (melatih siswa untuk mampu menyelesaikan berbagai permasalahan yang dihadapi), 2) SelfDirected Learning (memupuk dan melatih rasa tanggung jawab, inisiatif dan kebebasan untuk belajar mandiri), 3) Creative Thinking (melatih kemampuan daya kreasi siswa dalam menciptakan hal-hal baru), 4) Real World Connection (melatih siswa untuk menghubungkan konsep yang diperoleh dalam pembelajaranagar dapat diaplikasikan dalam penyelesaian permasalahan di dunia nyata), 5) Cooperative dan Collaborative Learning (melatih siswa untuk saling berbagi dan bekerja sama dengan orang lain), 6) Refleksi (siswa berlatih untuk mampu mengemukakan dan menceritakan kembali pengalaman belajar yang telah mereka peroleh), 7) Authentic Material (ada produk nyata hasil karya siswa). (Gora, 2009, h. 4).

\section{METODE}

Rancangan penelitian ini adalah Penelitian Pengembangan yang bertujuan untuk menghasilkan sebuah produk yaitu Pengembangan "Model Project-Based Learning" plus VCD pembelajaran untuk meningkatkan kemampuan Bahasa Inggris siswa Ponpes Modern di Malang Raya.

\section{Lokasi dan Subyek Coba}

Subyek coba dari penelitian ini adalah 28 orang siswi SMA Pondok Modern Al-Rifaie, Kelas X IPA-1 yang berlokasi di Jalan Raya Ketawang No. 1 Gondanglegi, Kabupaten Malang yang tinggal di dalam pondok (boarding).

\section{Model Pengembangan}

Model pengembangan produk yang digunakan adalah Model Pengembangan Borg dan Gall (1989) dengan sepuluh tahap dalam penerapannya, yaitu: pengumpulan informasi, pengembangan produk awal, validasi ahli 1 , revisi produk, validasi ahli 2 , revisi produk 2, try out, dan produk akhir.

Diawali dengan pengumpulan informasi yang berkaitan dengan mata pelajaran Bahasa Inggris yang diberikan di
SMA Pondok Modern Al-Rifaie Gondanglegi, antara lain mereview material yang digunakan dalam pembelajaran Bahasa Inggris, mempelajari silabus yang telah ditetapkan oleh SMA Pondok Modern AlRifaie Gondanglegi dan melakukan analisa kebutuhan dengan jalan observasi, interview, diskusi, dan memberikan angket kepada pihak-pihak yang terlibat dalam pembelajaran Bahasa Inggris di SMA Pondok Modern Al-Rifaie Gondanglegi, Malang.

Tahap perencanaan dengan membuat kerangka kerja dari pengembangan "Model Project-Based Learning" antara lain susunan dan tugas kerja tim, surat ijin, schedule, rancang instrument, dana, sarana prasarana.

Peneliti mengembangkan "Model Project-Based Learning" untuk meningkatkan kemampuan Bahasa Inggris siswa Ponpes Modern di Malang Raya berdasarkan beberapa informasi yang telah diperoleh dari fase pertama yang mana akan dihasilkan peta konsep tentang pengembangan "Model Project-Based Learning" plus VCD pembelajaran yang disesuaikan dengan silabus dan tema yang ada.

Kegiatan yang dilaksanakan dalam pengembangan "Model Project-Based Learning" adalah menciptakan proyek dalam pembelajaran Bahasa Inggris yaitu siswa berkelompok membuat proyek yaitu : 1) Portofolio Jenis Announcement Text, 2) Mading tema Announcement Text, 3) Merekam Performa Teman.

Dari peta konsep tersebut akan dikembangkan produk awal penelitian ini, yaitu berupa pengembangan "Model ProjectBased Learning" yang divalidasi oleh dua orang ahli dibidang Bahasa Inggris dan seorang ahli media.

Setelah menyelesaikan produk awal berupa pengembangan "Model Project-Based Learning" plus VCD pembelajaran, fase selanjutnya yaitu validasi produk oleh para ahli. Proses validasi Ahli Materi Bahasa Inggris berfokus pada RPP, tema dan desain proyek.

Proses revisi dilakukan berdasarkan komentar-komentar yang diberikan oleh para ahli. Proses validasi dan revisi dilaksanakan dua kali untuk masing-masing ahli agar menghasilkan produk yang benar-benar dirasa sudah baik dan siap untuk diujicobakan. 
Sebagai permulaan uji coba kelompok kecil dilaksanakan untuk mengetahui kelayakan, manfaat, efektifitas dari "Model Project-Based Learning" plus VCD pembelajaran.

Produk akhir dari penelitian ini adalah pengembangan "Model Project-Based Learning" plus VCD pembelajaran untuk meningkatkan kemampuan Bahasa Inggris siswa Ponpes Modern di Malang Raya.

Pengumpulan data penelitian yang digunakan adalah: (1) dokumentasi, interview dan observasi yang digunakan untuk memperoleh informasi awal dalam tahap penyusunan "Model Project-Based Learning", (2) kuesioner digunakan untuk menggali data kualitatif, 3) format validasi yang digunakan untuk memperoleh komentar dan saran dari para ahli untuk revisi dan validasi produk, 4) penilaian proyek.

Hasil yang dicapai dalam penelitian yang mengacu pada Tujuan Penelitian, yaitu untuk menghasilkan produk Pengembangan "Model Project-Based Learning" plus VCD pembelajaran untuk meningkatkan kemampuan Bahasa Inggris siswa Ponpes Modern di Malang Raya.

\section{DISKUSI DAN TEMUAN}

Langkah-langkah Pengembangan "Model Project-Based Learning

Pengembangan "Model Project-Based Learning" diawali dengan studi pendahuluan dengan menggunakan studi literatur dari berbagai sumber. Dilanjutkan dengan pengumpulan informasi dari studi lapang berkaitan dengan analisa kebutuhan (need analysis).

Tahap I dimulai dengan membuat kerangka kerja dari pengembangan "Model Project-Based Learning" antara lain dengan membuat peta konsep, susunan dan pembagian tugas kerja tim peneliti, menentukan siapa para Tim Ahli, Kordinator Lapangan (Korlap) dan Guru model yang akan mendukung penelitian.

Tahap II yaitu pengembangan awal produk yaitu Pengembangan "Model ProjectBased Learning" untuk meningkatkan kemampuan Bahasa Inggris Siswa Ponpes Modern di Malang Raya. Diawali dengan informasi dari studi lapang tentang Need Analysis, Kurikulum yang dipakai, Silabus, Program Semester, RPP, Kalender Akademik, nama siswa, buku teks Bahasa Inggris yang mengacu pada Kurikulum 2013.

Dari hasil rapat kerja tim peneliti dibuatlah sebuah rancangan awal yaitu RPP dengan tema Announcement Text yang mengacu pada Kurikulum 2013 yang sudah dilaksanakan pada semester II tahun Akademik 2013-2014 Kelas X IPA-1 di SMA Pondok Modern Al-Rifa'ie, Gondanglegi, Malang.

Tahap ke III adalah Validasi produk awal dari Ahli Bahasa Inggris 1 dan Ahli Bahasa Inggris 2. Lembar validasi para ahli Bahasa Inggris dibuat oleh tim peneliti berfokus pada RPP yang mencakup materi pembelajaran, alokasi waktu, langkahlangkah pembelajaran (dengan scientific approach), refleksi, dan penilaian.

Diskusi dengan Ahli Media meliputi pembuatan story board/naskah video, durasi waktu, pemilihan setting, sedangkan produk akhir akan diselesaikan setelah proses editing.

Tahap IV adalah Revisi Produk dilakukan oleh para ahli Bahasa Inggris dengan menggunakan lembar validasi yang sudah diberi komentar dan masukan berkenan dengan Pengembangan "Model Project-Based Learning" antara lain revisi RPP.

\section{Uji Coba Model}

Subyek uji coba model atau kelompok kecil adalah siswa Kelas X IPA-1 SMA Pondok Modern Al-Rifa'ie, Gondanglegi, Malang. Tahap Uji coba "Model Project-Based Learning" adalah pelaksanaan kegiatan Video Shooting penerapan langkah-langkah kegiatan dari pengembangan "Model ProjectBased Learning".

\section{Tahapan Pelaksanaan}

Pelaksanaan video shooting mengacu pada scenario/storyboard yang sudah dibuat Tim. Pelaksanaan video shooting dilaksanakan selama 5 kali pertemuan dengan Tema Announcement Text.

\section{Pertemuan I}

Kegiatan PBM fokus pada pemantapan materi di semester 2 yaitu tema Announcement Text dan langkah-langkah pembelajaran mengacu pada kurikulum 2013 dengan pendekatan saintifik (scientific 
approach) (kegiatan $5 \mathrm{M}$ yaitu mengamati, menanyakan, mengeksplorasi, mengasosiasi dan mengkomunikasi).

\section{Pertemuan II}

Kegiatan PBM fokus pada materi contohcontoh announcement text dan scaffolding dengan tugas Proyek 1 Portofolio yaitu siswa mencari Announcement Text dari sumber internet secara individual yang nantinya akan dijilid sebagai Portofolio.

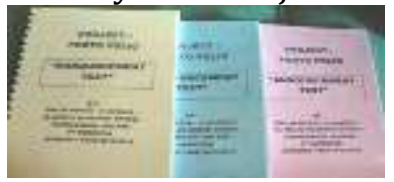

\section{Pertemuan III}

Kegiataan PBM fokus pada kegiatan kolaborasi (kelompok) dengan membuat karya nyata (authentic material) sebuah Mading (Proyek 2) yang bertema Announcement Text. Siswa berkelompok menciptakan sebuah Mading 3D dengan bahan-bahan yang mudah didapat (daur ulang).

\section{Pertemuan IV-V}

Kegiataan PBM fokus pada kegiatan mendisplay di papan display hasil karya Mading (Proyek 2) dari 5 kelompok. Kemudian kegiatan dilanjutkan dengan mengkomunikasikan Announcement dan siswa lain merekam (Proyek 3).

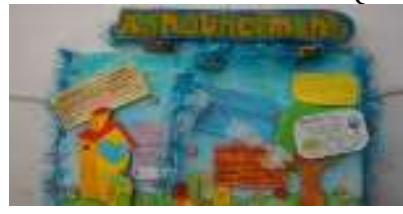

\section{Hasil Analisa Data Studi Pendahuluan}

Hasil dari observasi dan interview di lapangan (need analysis) diindentifikasi suatu permasalahan yaitu Guru-guru mengalami kendala dalam menerapkan model-model pembelajaran yang bisa meningkatkan kemampuan Bahasa Ingggris.

Hasil analisa data kuesioner siswa menunjukkan $71 \%$ siswa termotivasi untuk belajar Bahasa dan $25 \%$ siswa sangat termotivasi untuk belajar Bahasa Inggris. Sebanyak $71 \%$ siswa sangat setuju untuk menggunakan media pembelajaran. Ditambah pula sebanyak $71 \%$ siswa setuju jika guru menggunakan materi pembelajaran berfokus pada materi autentik, pembuatan proyek dan bekerja dalam kelompok yang sesuai dengan karakterisik "Model ProjectBased Learning".

\section{Produk Akhir}

Produk akhir dari penelitian ini adalah "Model Project-Based Learning" plus VCD pembelajaran yang disempurnakan dengan tahap revisi dan validasi Ahli Media.

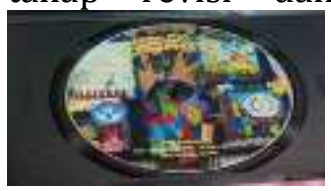

Aspek-aspek yang divalidasi oleh Ahli Media antara lain: tampilan luar VCD pembelajaran, isi VCD, kesesuaian VCD dengan RPP, penggunaan bahasa dalam VCD, durasi waktu, efek suara dan efek video, yang secara umum hasil validasi ahli media sangat baik dan VCD pembelajaran adalah layak untuk disajikan sebagai hasil produk akhir pengembangan "Model Project-Based Learning".

\section{Hasil Evaluasi Ahli Materi}

Hasil evaluasi Ahli Materi Bahasa Inggris 1 dan 2 menunjukkan hasil skor 5 dengan kategori Sangat Baik untuk Aspek Perumusan tujuan pembelajaran meliputi : kejelasan dan kesesuaian SK dan KD, kesesuaian SK dan KD dengan tujuan pembelajaran, ketepatan pejabaran KD kedalam indikator, kesesuaian indikator dengan tujuan pembelajaran, kesesuaian indikator dengan perkembangan siswa.

Dari Aspek Isi yang disajikan mendapat skor 4 dengan kategori baik meliputi sistematika penyusunan RPP, kesesuaian kegiatan pembelajaran dengan penerapan "Model Project-Based Learning", kejelasan langkah-langkah pembelajaran yang mengacu pada penggunan "scientific approach" dari Kurikulum 2013 (kegiatan mengamati, mempertanyakan, mengeksplorasi, mengasosiasi, dan mengkomunikasi). Ditambah pula dengan Skor 4 untuk kategori Baik dalam aspek kesesuaian materi dengan tujuan pembelajaran, pengggunaan bahasa dan alokasi waktu.

Saran dan tangggapan dari Ahli Materi Bahasa Inggris 1 yaitu Penyusunan RPP 
hendaknya disesuaikan dengan kaidah penulisan yang ditentukan BSNP. Sedang saran dari Ahli Materi Bahasa Inggris 2 yaitu Pemilihan Media dan materi pembelajaran hendaknya disesuaikan dengan kondisi dan karakter siswa Ponpes Modern.

\section{Hasil Evaluasi Ahli Media}

Hasil evaluasi Ahli Media terhadap produk akhir berupa VCD pembelajaran menunjukkan kategori Sangat Baik dengan Skor 5 pada Aspek tampilan luar yaitu kemenarikan dan kesesuaian gambar cover dengan karakter siswa Ponpes Modern.

Aspek Isi VCD pembelajaran, kemenarikan dan ketepatan pemilihan gambar cover, kualitas gambar gerak, kualitas suara, kejelasan isi.

Sedangkan pada aspek kesesuaian VCD dengan RPP, penggunaan bahasa, durasi waktu, efek suara, efek video sama mendapat skor 5 dengan kategori Sangat Baik. Tanggapan dari Ahli Media: sebagai media pembelajaran produk ini sudah baik dan sangat layak untuk diaplikasikan.

\section{SIMPULAN}

Mengacu pada tujuan penelitian Tahun ke-1 adalah untuk menghasilkan produk pengembangkan Model Project
Based-Learning" plus VCD pembelajaran untuk meningkatkan kemampuan Bahasa Inggris siswa SMA Ponpes Modern di Malang Raya, maka hasil produk akhir dari pengembangan "Model Project BasedLearning" plus VCD pembelajaran ini dapat memecahkan masalah-masalah yang dihadapi oleh guru dan siswa sesuai dengan analisa kebutuhan pada awal studi pendahuluan di SMA Pondok Modern AlRifa'ie Gondaglegi, Malang.

Validasi Ahli Materi Bahasa Inggris menyimpulkan bahwa perumusan tujuan pembelajaran, isi, pemilihan materi dalam Pengembangan "Model Project-Based Learning" sudah sesuai dengan standart BNSP dengan skor 5 kategori Sangat Baik.

Hasil validasi Ahli Media menunjukkan hasil yang sama dengan skor 5 kategori Sangat Baik dan layak untuk dijadikan sebagai media pembelajaran.

Pengembangan Model "Project-Based Learning" plus VCD pembelajaran ini merupakan karya inovatif yang dapat menjawab permasalahan yang dihadapi oleh guru-guru di Ponpes Modern di Malang Raya, yaitu bagaimana menerapkankan modelmodel pembelajaran yang mengacu pada pengembangan kurikulum 2013.

\section{DAFTAR PUSTAKA}

Borg, R.W., \& Gall. M.D. (1989). Educational Research: An Introduction (4th ed.). New York and London: Longman Inc.

Colley.K. (2008). Project-Based Science Instruction: A Premier. An Introduction and Learning Cycle for Implementation Project-Based Science. The Science Teacher Vol. 75. (8): 23-28.

Gora.(2009). Menggagas Penerapan Strategi PJBL (Project Based Learning) untuk Bidang Studi Teknik Informatika. http:// gora.wordpress. com/2009/11/13/ menggagas-penerapanstrategi-PjBL-project-based-learning. diakses 23 Maret 2013.

Hodgin. (2010). Project Based Learning: What is it?http://www.yesnet.yk.ca/ schools/wes/what_is_PjBL.html. diakses 21 Maret 2013.

Lisminingsih. (2010). Pembelajaran Berbasis Proyek: Alternatif Model Pendidikan Lingkungan Hidup untuk Meningkatkan Kecakapan Hidup. Jurnal Paradigma Tahun XV, Nomor 30, Juli Desember 2010. IKIP Budi Utomo Malang.

Mashudi. (2009). Strategi Pengembangan Pendidikan Islam di Pondok Modern Al-Rifa'ie, Gondanglegi, Malang. Unpublished Thesis. UIN Maulana Malik Ibrahim, Malang . 
Mulyasa. H.E. (2013). Pengembangan dan Implementasi Kurikulum 2013. Bandung. PT Remaja Rosdakarya.

Saifudin, Ahmad. (2011). Pengembangan Media Pembelajaran Berbasis Komputer Mapel IPS SMP. Jurnal Falasifa, Vol. 1 No. 2. September 2011.

Sugiyono. (2013). Metode Penelitian Pendidikan. Pendekatan Kualitatif, Kuantitatif dan $R \& D$. Bandung. CV. Alfabeta

http://id.wikipedia.org/wiki/daftar-pesantren-malang.htm. diakses 25 Maret 2013.

http://www.alkhoirot.net/2011/09/pondok-pesantren-modern.html.diakses 1 Juli 2014. 